\title{
The Writer as Reporter: Portraiture in Literary Reportage and Documentary Writing
}

\author{
Jerome Boyd Maunsell
}

University of Roehampton, London

\section{ABSTRACT}

This article explores how several novelists in the first half of the twentieth century, including James Agee, Jack London, George Orwell, and John Steinbeck, portrayed other, often marginal, real lives in works of reportage and documentary writing - terms variously defined and utilised by critics and practitioners, but seen here as hybrid, intersecting forms of life writing. It argues that such work has an extremely artful element of verbal portraiture of real-life people, often in dialogue with photography. The process of writing and witnessing reportage work differs substantially from that of fiction. Focusing on certain factors key to the portraiture in reportage-including unfamiliarity, representativeness, standpoint, and objectivity - the article analyses these writers' treatment of them. The extent to which these writers revealed their documentary or reportorial role to their subjects, or disguised it, is also considered. Moving between international, cultural, political and social contexts, and deeply informed by chance and accident, early twentieth century reportage emerges as a highly interactive, volatile, and intersubjective space in its portraiture of others, nonetheless defined finally by the writer's point of view.

Keywords: reportage; documentary writing; literary journalism; portraiture

The late Polish writer Ryszard Kapuściński, who died in 2007, defined his own work as 'literary reportage': a hybrid form of writing at the intersection of autobiography, biography, fiction, history, journalism, reporting, and travel writing, in which, as Kapuściński declared, 'authentic events, 
true stories and accidents are described with language containing the writer's personal opinions and reactions and often fictional asides as added colour' (51). This genre, if we can call it that-and Kapuściński's statement here is open to question especially in its inclusion of its most contentious ingredient, ${ }^{1}$ 'fictional asides'-has a long history. Work by writers from the seventeenth to the nineteenth centuries, including Daniel Defoe and Charles Dickens, can be seen in the early lineage of reportage (Kerrane, 17). Literary reportage has also been given various other names, during different contexts even in the twentieth and twenty-first centuries. In the Thirties in America and Britain, works of this type were often called 'documentary', a term said to have been coined by the film producer John Grierson in a New York Sun review of Robert Flaherty's Moana in 1926, and defined by Grierson as 'the creative treatment of actuality' (McLoughlin, 51). ${ }^{2}$ As William Stott argues, documentary emerged as a literary genre in the years after the First World War, and was conceived as 'fiction's opposite': its essence 'the communication, not of imagined things, but of real things only' (xi). It had precursors in the muck-raking and investigative journalism practised in the eighteen nineties, and was also influenced by debates about propaganda during and after the First World War, when government manipulation of the 'news' caused many to lose their faith in 'straight' journalism, and to question how much 'facts' could be trusted (Schudson, 6-7).

In 1935, the term 'reportage' was introduced in America, as the title of a congress paper by Joseph North, editor of the Communist-leaning New Masses, who asserted that 'Reportage is three-dimensional reporting. The writer not only condenses reality, he helps the reader feel the fact' (121). North was importing the tag 'reportage' from Europe: in Russia in the Twenties and Thirties, influenced by Russian Formalism, Sergei Tretyakov and Valentin Kataev wrote 'factographic' reportage, while the Czech writer and journalist Egon Erwin Kisch also proclaimed the importance of reportage over the novel as a literary form: 'Novel? No. Reportage!' (as quoted in Hartsock, 'Literary Reportage', 119). Walter Benjamin, writing of Tretyakov in 'The Author as Producer' in 1934, noted how Tretyakov's work forced a reconsideration of all existing notions of genre, and again referred back to the novel: 'we must rethink the notions of literary forms or genres if we are to find forms appropriate to the literary energy of our time. Novels did not always exist in the past, nor must they necessarily always exist in the future' (89).

In America in the Sixties, non-fictional writing of a similar type (though shorn of its Marxist and Communist underpinnings) was called 'The New Journalism'-described by Tom Wolfe as 'journalism that would [...] read like a novel' (21-2); ${ }^{3}$ Gabriel García Márquez, meanwhile, in Mexico 
City and Cuba, pioneered 'nuevo periodismo'. The emerging Cold War context postwar was an important factor in the development of the New Journalism; Vietnam and Watergate also caused many, once again, to doubt 'official' news reports and reporting methods, and to think about alternative ways of reflecting situations in more depth. More recently, similar forms of writing have been called 'literary journalism' in America. ${ }^{4}$

For all these different terminologies and agendas, nonetheless, there are many similarities between all these forms-especially in their hybridity and engagement with reality. Indeed, when compared with other literary genres, the interactive, reality-oriented nature of reportage work marks it out as profoundly different, in process, from the novel, the short story, or the poem. In some ways, it is closer to a radical literary repurposing, avant la lettre, and in reality rather than the gallery, of what Nicolas Bourriaud, in the art world, has called 'relational aesthetics': 'a set of artistic practices which take as their theoretical and practical point of departure the whole of human relations and their social context, rather than an independent and private space' (113).

The relationship of fact and fiction in all such writing, however one labels it, has often been a dominant concern, as reportage and documentary writing, the terms I use most here, broadly fall under the umbrella of non-fiction, ${ }^{5}$ and, above all, of what has been termed 'creative nonfiction'. Rather than the fact-fiction debate, this article, however, focuses on the element of portraiture of real people in reportage, taking in several examples by novelists in the first half of the twentieth century, who all faced similar problems while working on reportage projects: James Agee, Jack London, George Orwell and John Steinbeck. These four writers, working on reportage individually at different points across this period, but most of all in the late Thirties and Forties, counterpoint each other in the article, which draws out central issues in their written portraiture of other people. While these are all well-known (and hardly diverse in terms of gender ${ }^{6}$ Anglo-American novelists of the period, and while some of their reportage is extremely prominent, attracting a good deal of scholarship, very little has been said by critics to date about this specific element of portraiture in their reportage and how it operates. I focus above all here on economic and geographic disparities (or otherwise) between these writers and many people they portray in their reportage: further studies could extend this work into other areas including gender, ethnicity, and religion.

Portraiture, generally, has been more often analysed in works of visual art (especially painting, before photography) than in non-fictional writing; and it has often proven notoriously difficult to define. My conception of portraiture in this article encompasses both written portraiture 
in prose, and photographic portraiture. And by portraiture-adapting Richard Brilliant's definition-I mean a likeness made by a writer or photographer of another living person. ${ }^{7}$ Once we think of reportage in terms of this kind of portraiture, we discover that while written reportage often concentrates on a political or social situation, conflict, or issue, it alsolike other forms of life writing, especially autobiography, biography and group biography-offers numerous portraits of real people, as the writer describes characters met along the way. As we will see, the explosion of photographic portraiture during this period had a palpable effect on written reportage, as three of these writers (Agee, London and Steinbeck) incorporated photography in their books of reportage, either taking photographs themselves or collaborating with photographers; thus issues encountered in the verbal and visual field illuminate each other particularly well.

\section{ASPECTS OF PORTRAITURE IN REPORTAGE}

What are the distinctive qualities and techniques of the portraiture in reportage? As I argue, during this period, the depiction of marginal lives is one major issue. Unfamiliarity, representativeness, standpoint, objectivity and intersubjectivity are other central themes which I define further and expand on in what follows.

Much more so than traditional biography, reportage often portrays obscured lives, and lives which would otherwise have been occluded from the historical record. In this, it can be aligned with forms of life writing 'from below', ${ }^{8}$ although the portraits and voices it contains of lives on the margins are mediated by the writer-reporter. In recent decades, as T.G. Ashplant observes, 'literary scholars have come to recognise, beyond traditional autobiographies, a much wider range of texts which narrate the self' (18). This widening of the sphere of life writing studies converges strikingly with the aims of documentary writing and reportage. Kay Schaffer and Sidonie Smith, writing about contemporary life narratives in the field of human rights, note that 'through acts of remembering, individuals and communities narrate alternative or counter-histories coming from the margins, voiced by other kinds of subjects-the tortured, the displaced and overlooked, the silenced and unacknowledged' (4).

This is also the territory of much reportage, which, along with 'literary journalism', in John S. Bak's words, 'raises our socio-political awareness about a disenfranchised or underprivileged people' (1). Reportage has frequently been conceived as a genre as a mode of recapturing and representing ordinary life, often with a political (leftist) agenda, or as a way of making the usually invisible seen. As Stott observes, 'documentary is a 
radically democratic genre. It dignifies the usual and levels the extraordinary' (49). Jeff Allred concurs that it brings 'a sense of direct encounter with "forgotten" subjects who are frequently excluded from cultural representation' (29). In this widening of frontiers reportage is radically unifying. But the portrayal of these lives is also freighted with difficulties and responsibilities for the writer.

Unfamiliarity is another intrinsic aspect of the portraiture in reportage. Often, those depicted are initially strangers to the writer, and there are social, cultural, international or linguistic differences to surmount. Characters in reportage are often merely glimpsed, or the amount of time in which the writer sees them or speaks with them is severely constrained or limited. The element of chance in reportage is also a key aspect of its portraiture, as Kapuściński's definition hints, referring to 'accidents'. Reportage is, indeed, so rooted in arbitrariness that it verges towards the Surrealist. James Agee almost acknowledges this odd closeness between Surrealism and reportage, when he suggests how Let Us Now Praise Famous Men (1941), his collaboration with the photographer Walker Evans about three sharecropper families in Alabama, would ideally consist, not of writing, but of things themselves-'fragments of cloth, bits of cotton, lumps of earth, records of speech, pieces of wood and iron, phials of odours, plates of food' (10) — which recall Marcel Duchamp's 'readymades'. ${ }^{9}$ The people figured and depicted in reportage are frequently found by trial and error, plucked from the rest of humanity by chance. Martha Gellhorn, in Poland in 1958, highlights the sheer randomness of her reporting technique:

I had no introductions, could not speak a word of Polish, and stood on the street in front of my Warsaw hotel wondering whether I was a certifiable nutcase. How did I expect to do this job I had assigned myself? For want of a better idea, I walked down the street and saw an art gallery [...] The young painfully thin artist $[\ldots]$ happened to be in the gallery at the time [...] We talked [...] I met everyone like that; one handed me on to another (175).

Despite such aleatory procedures, portraits in reportage, often problematically, are often concerned to make people seem part of a wider whole. The art critic Bernard Berenson complained that portraiture in painting, when overly concerned with representativeness or social 'type', was no longer portraiture at all, becoming mere 'effigy' (as quoted in Gidley, 138). In literary reportage, people seen in time of war are frequently depicted primarily to illuminate a political situation; or people experiencing poverty are shown as representative social examples. The directive of the writer to make characters representative inflects the resulting portraits. 
Kate McLoughlin has stressed the way in which positioning, or standpoint, in war reportage is vital: 'how the conflict is written about is radically affected by the stance, and hence the standing, of the recorder' (1). The same is true of all the portraiture in reportage and documentary writing, which is often highly mobile, interactive and volatile. Such positioning, as McLoughlin notes, has many aspects, occurring both during the process of reporting 'in the field' by a 'flesh-and-blood recording individual' (2) and in how this process is then represented in the resulting text. Many different variables are in play: 'status; presence; priority; proximity; perspective; dress and comportment' in the field; 'tone, voice, "objectivity" or "subjectivity" in the text (2).

Objectivity, in particular, needs careful definition. In mainstream journalism in America since the mid-nineteenth century, the notion of 'objectivity' has been a key tenet of reportorial professionalism, even if, today, as Michael Schudson writes, 'it holds its authority on sufferance' (10). It is a concept, and a set of procedures, with a long history of its own, with varying meanings, as many scholars of journalism have shown. Its main principles include factuality, fairness, non-bias, independence, non-interpretation, neutrality and detachment (Ward, 19). For Steven Maras, "perhaps the most succinct definition of objectivity is provided by Walter Cronkite: "Objectivity is the reporting of reality, of facts, as nearly as they can be obtained without the injection of prejudice and personal opinion" (6). Looking at reportage in terms of its portraiture doesn't necessarily impinge on the factuality of reportage, but it certainly throws its impartiality and impersonality into question, in a way that aligns with the ceaseless re-examinations of the concept of objectivity which have haunted journalism for the past half century or more.

Writers operating in the role of reporter sometimes attempt an observing, detached stance-and do, however impossibly, try to aim for 'objectivity'. Or, conversely, they can become very actively involved with their subjects. Like biographers, they also face difficulties of access; and they share the biographical issues of privacy, ethics, and appropriate revelation of other people's lives. As in all portraiture, the depiction of other people in reportage often depends as much upon the background of the writer as the subject.

Art historians write of the 'portrait transaction' in painting, involving 'a perpetual oscillation between observer and observed' (Woodall, 21), with social status being intricately bound up with such exchanges. ${ }^{10}$ Yet as Luke Seaber writes of a closely related subgenre, which he calls 'incognito social investigation', 'the simple dichotomy of observer and observed is inadequate' to pin down the portraiture in reportage, which opens 
up 'questions of performativity and intersubjectivity': 'these are texts wherein authors' lives are written under the guise of describing the lives of others; these are texts wherein authors record themselves changing without their realizing it, and record other lives' (2). To different degrees in specific reportage projects, the observer and the observed often interact upon, and influence each other-making intersubjectivity, where there is an interplay between subject and object, a more appropriate term than mere subjectivity or objectivity, chiming with Linda Nochlin's observation that 'the portrait demands the meeting of two subjectivities' (29). This interactive element in reportage can be very fluid, yet it is also far from seamless and without misunderstandings. As Robert Coles suggests in Doing Documentary Work, the often radical unfamiliarity of the portraits in reportage is frequently a result of various barriers being crossed; and 'the documentarian [...] can be both a vehicle and an obstacle on a journey' (43).

What happens when the observed is unaware of the observer, the reporter or documentarian, or of the observer's recording role, as frequently occurs in both written and photographic portraiture? One definition of portraiture, by the American photographer Richard Avedon, particularly famous for his studio portraits, sheds a revealing light on the invisibility (or otherwise) of the writer and photographer to the subject. For Avedon, a portrait was 'a picture of someone who knows he's being photographed, and what he does with this knowledge is as much a part of the photograph as what he's wearing or how he looks. He's implicated in what's happening, and he has a certain real power over the result. The way someone who's being photographed presents himself to the camera and the effect of the photographer's response on that presence is what the making of a portrait is about' (as quoted in Jackson, 'Pictures from a Drawer', 41-2).

This would discount many portraits in reportage from being portraits at all. In many of the portraits in written and photographic reportage, the subject has no knowledge of being portrayed. Or, crucially, there can be an element of disguise at play. Sometimes, and more surprisingly, the observer is also being observed (by someone entirely outside the frame, as it were), as we will see, and with equally important consequences for the final portrait produced. Avedon's definition would also exclude the work of many street photographers, such as Garry Winogrand or PhilipLorca DiCorcia. Many of Winogrand's shots of 'unaware-or wary too late-pedestrians' were also unseen, even by the photographer, who left behind 'several thousand [...] undeveloped rolls of film' (Schjeldahl, 60). Yet Avedon was to backtrack on this conception of photographic portraiture. A few years later, in an interview with Nicole Wisniak, he changed 
his mind about its power dynamics, in a dramatic about-turn which has extensive relevance for writer-reporters as well as photographers:

I used to think that it was a collaboration, that it was something that happened as a result of what the subject wanted to project and what the photographer wanted to photograph. I no longer think it is that at all. The photographer has complete control, the issue is a moral one and it is complicated (as quoted in Jackson, 42).

\section{TEMPORARY EQUALITY: ORWELL IN PARIS AND LONDON}

In the Thirties documentaries of George Orwell, one can trace the ways in which familiarity and unfamiliarity serve as filters in reportage, as the writer is sometimes too close to something to see it clearly, or too estranged to understand it; while in other cases unfamiliarity can, surprisingly, create clarity, recognition and vividness. Unfamiliarity, then, is profoundly double-edged in its effects. As Henri Cartier-Bresson puts it: 'The first impression given by a particular face is often the right one; but the photographer should always try to substantiate the first impression by "living" with the person concerned' (31). The same observation applies to writers, as Orwell's documentary work bears out.

At the outset of his first book, Down and Out in Paris and London (1933), Orwell draws attention to the unfamiliar lives he has chronicled, highlighting the element of verbal portraiture; and his interest stems in part from a sense of novelty about his characters. Writing of 'Monsieur Jules', 'Fureux the Limousin stonemason', and 'old Laurent the rag-merchant', Orwell notes that 'it would be fun to write some of their biographies, if one had time. I am trying to describe the people in our quarter, not for the mere curiosity, but because they are all part of the story' (5). Thus Orwell almost frames his book early on as an experiment in biography. But he then subsumes these figures in the wider theme: "poverty is what I am writing about' (5).

More than Orwell's later documentaries The Road to Wigan Pier (1937) and Homage to Catalonia (1938), Down and Out was actually a blend of fact and fiction. ${ }^{11}$ In 1935, Orwell declared that he had 'refrained, as far as possible, from drawing individual portraits of particular people' (A Kind of Compulsion, 353) - and he emphasised that his characters were representative types, rather than specific individuals, as if this was a positive quality. Part of this disavowal was precisely because Down and Out is so close to being a sequence of such portraits, and Victor Gollancz, Orwell's publisher, was extremely aware of potential legal problems, even though the author's real identity as Eric Blair was concealed by the pseudonym 
'George Orwell', and the names of any people portrayed would have been changed.

Orwell's texts on poverty are tied to the ethical problems of how one should depict the unfortunate, and how this relates to the writer's own standpoint-a term I'm using here primarily in terms of economic, international, and class perspectives. In Down and Out, the sense of unfamiliarity is blurred, as there is an unresolved ambiguity about Orwell's position, as he withholds how his early poverty was, at least partially, chosen by him as a role. The text itself is ambiguous even about the narrator, who is never named either as Blair or as Orwell, and who, in the London sections, adopts various 'covers' and disguises in order to pass as a tramp, calling himself a painter or journalist (209) - guises themselves suggesting the extent to which Orwell saw his work as being analogous to portraiture.

In Down and Out, the standpoint shifts elusively. Generally, however, the narrator is not all that distanced from the poor characters he describes: he is one of them, if only, we infer, for a time. Insecure as he undoubtedly was in reality during this period, Orwell's position was better than he lets on in the book. But the placing of his narrator as down and out himself crucially allows Orwell to draw the characters he meets with equality, with humour, and without the distanced pity that often informs such portrayals. ${ }^{12}$ Orwell does not attempt to make the poor admirable, and he is alive to their faults.

The sections of Down and Out on Paris and London are, as Luke Seaber observes, 'methodologically quite distinct': in Paris, Orwell lives and works in the city, while the London sections 'depict the wandering life of the homeless' (63). The portraiture in both sections also differs markedly. With the French characters, Orwell allows himself frequent dashes of foreign quirkiness, and the narrator's position as a stranger in a strange land also makes it natural that the encounters with these figures are transitory and quite fleeting-portraits also in the sense that they offer short vignettes, enclosed and brief. In the London sections, in the many short pen sketches of the tramps he encounters, Orwell transcribes the argot and the slang of this milieu with comic relish and particularity. The humour, especially, is perhaps surprising, but it is an essential part of Orwell's portraits. Writing of Paddy, 'the first tramp I had known at all well', Orwell avers that 'I believe that he was a typical tramp and there are tens of thousands in England like him' (159): the individual, as so often in reportage, melting into a depiction of an aspect of society. But the portrait of Paddy only gains force and poignancy through its details, and its most memorable moments through Orwell's fearless (and horribly condescending) mockery: 
He was a tallish man aged about thirty-five, with fair hair going grizzled and watery blue eyes. [...] (159) His ignorance was limitless and appalling [...] When I was looking into a bookshop window, he grew very perturbed because one of the books was called Of the Imitation of Christ. He took this for blasphemy. 'What de hell do dey want to go imitatin' of Him for?' (161).

The passage instantly reveals what writing can do that is distinct from visual portraiture, as well as exposing peculiarly writerly problems of tone, as it moves from a purely visual description into judgement, anecdote and mimicked speech. Alongside objectivity, the degree of dispassionate 'coldness' or involved 'warmth' to take towards living human subjects is another key aspect of all documentary work. In Down and Out, Orwell fuses camaraderie and warmth in his portrayals with a critical coldness which can seem, as in the portrayal of Paddy, cruel and patronising. But part of Orwell's documentary wager lies in his larger perception that to write critically and honestly, even meanly, of his characters, is to grant them a greater respect than a more self-censoring account would offer. This obviously does not apply to the much more deeply problematic, unthinkingly anti-Semitic aspect of a few of his sketches-for example, as Bernard Crick has noted, the 'nasty, indeed positively anti-Semitic anecdotes about the swindling Jew' (201). But generally in Down and Out, Orwell assumes he has earned the right to write as he wishes of his characters, from a position of temporary equality.

\section{'AN INVESTIGATOR, A SOCIAL STUDENT’: JACK LONDON}

In Jack London's The People of the Abyss of 1903, in which the American writer likewise chronicles the poor of the East End, the writer-reporter, more than Orwell, also emphasises how he travels in disguise. Styling himself an 'explorer' going 'down into the under-world' (17), London had a more convincing 'cover' than Orwell. As we see him telling various people in the book, his story was that he was " a seafaring man", who had spent his money in riotous living, lost his clothes [...] and was temporarily broke while looking for a ship' (69). London is also more explicit than Orwell about how his 'cover' and its temporary gift of equality with those he writes about enables him to extract stories from them. After walking from Whitechapel to Poplar Workhouse with two characters, a 'Carter' and a 'Carpenter', for example, London treats them to a meal at a coffeehouse. The revelation of his 'real' identity immediately changes the relations between them: 'Of course I had to explain to them that I was merely an investigator, a social student, seeking to find out how the other half lived. And at once they shut up like clams' (75). 
London's disguise as an unemployed sailor was not, however, all that far from the truth. His own roots were closer to poverty than he admitted in The People of the Abyss, and so he tended to exaggerate his distance from its characters. As Joan Hedrick puts it, 'London saw his old self in the English sailors and carters and dockers' (58); and the book offered a 'private burial of his working-class consciousness' (68). London returned to his own lodging - a rented room on Dempsey Street in Stepney (Labor, 164) — most nights after his episodes investigating poverty, as he makes clear. Where Orwell was keen to portray himself as semi-destitute, London wants to draw a thick line between his own circumstances and those he writes about.

Orwell read The People of the Abyss and in several scenes-for example, when London first changes into older, dirtier clothes-imitates it. Down and Out was a literary journey for Orwell as much as anything: he was following in London's footsteps. But the greater international distance London travels allows him even more freedom in his portrayals than Orwell. London emphasises, indeed over-emphasises, his Americanness throughout The People of the Abyss, linking it to his physical prowess. His short sketches of the unfortunate are sometimes luridly or ludicrously drawn, with lots of vernacular imitative dialogue.

London, like Orwell after him, sees that poverty can be described with raucous humour, and he values the lively slang and conversation with those he depicts for its literary power. Sometimes he uses reported speech to offer up a character's life story; or at other moments, he names a chapter after a character and devotes it entirely to one person. He often moves between detailed physical description of an individual and a wider statement of how they are part of a larger picture. Where Orwell writes dispassionately, even cruelly, about some of his figures, often with an eye for physical defects, London goes much further, his indignation about poverty leading to radically dehumanising passages of physiological disgust.

For all the vehemence, London also worried about his treatment of poverty. 'Sometimes I become afraid of my own generalizations upon the massed misery of this Ghetto life', he writes, 'and feel that my impressions are exaggerated' (170-1). And indeed, in many places The People of the Abyss is frankly sensational and over-elaborated, wrought to induce indignation in the reader, and a sense of the urgency of changing these conditions. The text has a hyperbolic tinge-as Iain Sinclair writes, it is 'reportage as a form of science fiction', 'a sleepwalker's nightmare journey through reeking underclass sets out of Henry Mayhew, Arthur Morrison, and Blanchard Jerrold (with apocalyptic engravings by Doré)' (13). It veers, as so much reportage inevitably does, towards polemic, or propaganda. 
But the early editions of the book, as Sinclair also points out, "came with hard evidence in the form of uncredited photographs' (14) reinforcing the portrait of squalor. London was an accomplished photographer. During the period from 1900-1916 he made more than 12,000 photographs..$^{13}$ In The People of the Abyss, London himself appears in one of the photographs towards the end, with a cobbler, captioned 'Bert and the Author Ready to Pick Hops' (135). Generally in his arrangement of the photographs, London is drawn to their utility as 'evidence', gravitating to street scenes and photographs of places he describes, while also being careful not to diminish the humanity of his subjects. In many of the photographs in The People in the Abyss, someone, or sometimes, a whole group of people, can be found looking straight back at the lens. Their gaze often speaks, more eloquently than London's heavily jaundiced text, of an affinity established between the writer and the subject.

The photographs in The People of the Abyss are often group portraits or portraits, but they are also frequently captioned to emphasise a general social point or how a specific figure is representative-for example, a portrait of a hop-picking couple labelled 'A Typical London Hopper and his Mate "Padding the Hoof" in Kent' (83). Framed, composed, imbued with chance, and hence deeply subjective, the photographs are not seemingly prized for these qualities, but for their aspect as fragments of reality. Some of these photographs have also been arranged, posed, or staged-such as the all-too-static shot of 'Conflict again Precipitated' (52) between two women, illustrating London's comic description of 'Drunken women fighting' narrated almost like a stage play (53). For all the immediacy of London's depiction of the women lunging at each other, he suggests that he did not actually see the fight, let alone photograph it. As Owen Clayton observes, London's photographs were sometimes composites, and he was also, at times, 'willing to fake images to create a spectacular effect' (206).

\section{ORWELL: FROM SOCIAL INVESTIGATION TO PARTICIPATION}

Orwell faced more profound problems of standpoint when he came closer to his own background, depicting the working-class, rather than the underclass, in The Road to Wigan Pier. He found it harder to travel in disguise. He stayed in a lodging-house for travelling salesmen, but he does not attempt the equality of viewpoint or the manic humour of Down and Out. When he makes barbed portrayals of his hosts, writing of Mrs Brooker, for example, as 'a soft mound of fat and self-pity' (10) or of $\mathrm{Mr}$ Brooker as 'a dark, small-boned, sour, Irish-looking man, and astonishingly dirty' (5), the grotesquerie has a bitter taste. Indeed, the opening 
verbal portrait of the Brookers in Wigan Pier is surely calculated as an affront, as Orwell tests how far he go in the vein of acid sketches of mild squalor and mediocrity, moving with suspicious ease from the particular to the general: 'But it is no use saying that people like the Brookers are just disgusting and trying to put them out of mind. For they exist in tens and hundreds of thousands; they are one of the characteristic by-products of the modern world' (14).

The verbal portraits in Wigan Pier are more representative than individual, deliberately so. Indeed, Orwell went to the coal mining areas of Lancashire and Yorkshire "partly because I wanted to see what massunemployment is like at its worst, partly in order to see the most typical section of the English working class at close quarters' (113). Orwell's method in Wigan Pier is more that of a social investigator than in Down and Out, as he visits coal mines and houses with the explicit intention of producing a contracted book, and often compiles statistical information. Looking into 'the housing question', for example, Orwell visited 'perhaps a hundred or two hundred houses altogether' (67), and his approach makes it inevitable that he should thus see people as parts of society, even while he sees the problems with this outlook: 'Alf Smith is merely one of the quarter million [unemployed miners], a statistical unit. But no human being finds it easy to regard himself as a statistical unit' (79).

While the Brookers are mocked and satirised, the miners are put on a pedestal by Orwell, at pains to show them as heroes. But unlike with the underclass, where Orwell found assimilation a mere matter of clothes and situation, with the working-class there was "no short cut into their midst' (144); and Orwell conceded that his portrayals were those of an outsider: 'though I was among them [...] I was not one of them, and they knew it even better than I did' (145). The 'class-difference', Orwell writes, 'confronts you' like 'the plate-glass pane of an aquarium; it is so easy to pretend that it isn't there, and so impossible to get through it' (145). This simile recalls Orwell's later statement in 1946 that 'good prose is like a window pane', while also looping back to the framing of an earlier scene in Wigan Pier, when Orwell saw, from the window of a train, a young woman unblocking a drain-pipe, and emphasised his simultaneous intimacy and estrangement: 'I had time to see everything about herher sacking apron, her clumsy clogs, her arms reddened by the cold. She looked up as the train passed, and I was almost near enough to catch her eye' (15). As Laura Marcus has suggested, this moment is intensely cinematic; and importantly, in his Wigan diaries, Orwell actually recounted seeing this woman in a side-alley, not from a train at all (203-4). As well as recalling the cinema, the train window also turns this haphazard visual encounter into a carefully framed, composed portrait. 
The photographs included in the original edition of Wigan Pier were assembled from diverse sources by Victor Gollancz (Williams, 172-3). As in London's The People of the Abyss, they enhance the documentary effect of 'objectivity'. Here, however, the photographs of miners, mining conditions and poor housing come from completely different locations, mainly in Wales and London, to the places Orwell is writing about. They are labelled and presented as being representative of the social problems described, rather than as individual portraits, even while they depict many people. But Orwell himself became increasingly aware throughout writing Wigan Pier that any attempt at objectivity would be a sham on his part, feeling that his work was 'an impertinence' (68), and offering, in the second half of the book, a polemical and autobiographical account of his own standpoint vis-à-vis class, utterly breaking the frame of objectivity to analyse the position from which he writes.

It is perhaps only after the tortuous throat-clearings and obsessively English class-convolutions of the second half of Wigan Pier that the opening scene of Orwell's next book, Homage to Catalonia (1938), makes total sense, as Orwell describes 'an Italian militiaman' (1) who shakes his hand, bridging language barriers and establishing instant equality. Once again, this scene suggests how greater cultural distance can sometimes allow for greater intimacy or, if not, daring and freedom in portraiture. After all of his problems with the 'plate-glass pane' of class in Wigan, Orwell, with his 'bad Spanish' (1), immediately feels closer to this stranger in Barcelona.

Homage to Catalonia likewise suggests how the depiction of people in war reportage fundamentally differs from the portrayal of poverty. For in Homage-nowhere more so than in the precise moment of being shot in the throat-Orwell once and for all sheds the difficulties of being an observer, and becomes an involved participant. The proximity to death and danger of even the most protected war correspondent often serves to elide many of the qualms that afflict chroniclers of poverty-even if questions over the consumption of war reportage by readers and viewers of such material clearly remain. The problem of photography in Homage does not concern point of view or representativeness, but rather, the simple fact that Orwell's camera, which he mentions having with him several times early on, was stolen from him (52-3).

While he was reporting on the Spanish Civil War, Orwell himself was being closely watched by the Communists, being spied on by David Crook, who was posing as a British journalist (Bowker, 216, 219). And by the end of Homage, Orwell's main aim is to escape from Spain alive. Perhaps this is why in Homage he shows none of the frustrated class-consciousness he reveals in Wigan Pier. Disguise becomes central to Homage towards its end, as Orwell pretended to be a wealthy English tourist, in order to evade capture by the Communists. In an inversion of his disguise as a tramp in 
Down and Out, at the close of Homage Orwell and his wife tried 'to look as bourgeois as possible. We frequented the fashionable residential quarter of the town [...] went to expensive restaurants and were very English with the waiters' (181). Unfamiliarity is exploited to save him, and the observer's greatest, and very real, concern is that he is being surreptitiously observed-a motif that would reappear more and more frequently in reportage work with the surveillance of the Cold War and Communist espionage.

\section{A 'SPY, TRAVELLING AS A JOURNALIST': JAMES AGEE}

Questions of standpoint also underlie James Agee's preface to Let Us Now Praise Famous Men, his book about three families in Alabama, begun the same year Orwell was in Wigan, in 1937-and whose very title attempts to shake up assumptions about the portrayal of ordinary or 'marginal' lives. The preface foregrounds Agee's anxieties about how his project was initially a magazine assignment to depict a 'representative' or 'average white family of tenant farmers' (xvii). As Agee's biographer Laurence Bergreen writes, Agee's title was chosen 'to emphasise with savage irony the obscurity of the three families about which he had written' (236). Agee's text goes on to strive to depict these families 'in as great and perfect and exact particularity as we can name them' (97) - but not before his deeply idiosyncratic 'preamble' had fully raked over the quandaries of what he was doing. 'It seems to me curious, not to say obscene and thoroughly terrifying', Agee writes, '[...] to pry intimately into the lives of an undefended and appallingly damaged group of human beings, an ignorant and helpless rural family' (5). And, notoriously, he continues in this vein, in a selfreflexive, stupendously accretive text which soars to heights of illumined lyricism and offers painstaking catalogues of fact, experimenting with form, language, and tone to convey 'human actuality' (xviii).

Like Orwell, Agee was also writing from a position of relative privilege which he found deeply problematic, and attempted, perhaps foolishly, to dissolve. His discomfort with his position as an intrusive observer is evident in his list of 'Persons and Places' before his narrative, where Agee describes himself as a 'spy, travelling as a journalist' and Walker Evans as 'a counter-spy, travelling as a photographer' (xxiv). But where Orwell treats some of his poor characters mischievously, even contemptuously, Agee veers towards hagiography, so full of his own trespass that he hardly writes a word in critique. In place of 'cool' observation, despite his self-avowed position as a 'spy' of sorts, Agee displays an alarmingly deep empathy towards his subjects, writing with a religious Romanticism which exalts everything he sees. At times the very reverence is patronising, and 
as Ella Zohar Ophir observes, Agee's stance 'renders Famous Men vulnerable to charges of solipsism, as though the abject poverty he confronts is reduced to an occasion for his personal ecstasies' (131). But Agee's concern to document every singularity of the individuals he depicts becomes a hymn to the particular which surpasses the portraits of people in the reportage of London and Orwell. "How am I to speak of you as "tenant" farmers, as "representatives" of your "class", as social integers [...]?' (88), Agee writes searchingly. For, as he declares (changing the real-life Burroughs family name to Gudger):

George Gudger is a human being, a man, not like any other human being so much as he is like himself [...] a much more important, and dignified, and true fact about him than I could conceivably invent $[\ldots]$ is that fact that he is exactly, down to the last inch and instant, who, what, where, when and why he is [205].

Agee's sense of his work as portraiture was emphasised by his collaboration with Walker Evans. Evans's photographs, opening the book without introduction or captions, immediately convey the full human presence of their subjects in ways that the photographs in London and Orwell do not. The lack of captions makes us see these people with an initial, unsettling unfamiliarity. And the first three photographs give us single subjects who stare back directly at us, whose expressions profoundly question our own gaze, before we see the further images of interiors, groups, and still-lives.

The camera, for Agee, represents an aesthetic ideal-he calls it 'the central instrument of our time' (9). When 'handled cleanly and literally in its own terms, as an ice-cold, some ways limited, some ways more capable, eye [...]', Agee writes, the camera is 'incapable of recording anything but absolutely dry truth' (206). Such naïve idealization of the 'truth' of the camera by Agee fails, it seems, to understand the ways in which photographic portraiture is often chance-inflected and intersubjective, sometimes even when the camera is hidden, or when the subject is unaware of being photographed. ${ }^{14}$ That said, Agee also writes, more subtly, that he can think of 'less than a dozen' photographers alive 'whose eyes I can trust' (9). He writes eloquently about the logistics and aesthetics of Evans's photography, which informs his own attempt in his words 'to see or to convey some single thing as nearly as possible as that thing is' (205) and 'to perceive simply the cruel radiance of what is' (9).

Jeff Allred has noted how the idea of documentary 'as evidence [...] catching life unawares' has, in critical conceptions of the genre, given way to the more complex notion of 'witness', in which documentary or reportage 'grows out of exchange, mutual regard, rapport' and 'may even 
incorporate into the text itself markers of the labor that went into its production' (18). And indeed, as Evans made some of his portraits, Agee portrays him in the text, riffing on the camera apparatus: 'Walker setting up the terrible structure of the tripod crested by the black square heavy head, dangerous as that of a hunchback, of the camera [...] a witchcraft preparing, colder than keenest ice, and incalculably cruel' (322). The camera here is sinister, magical, occult, impersonal. But it is also personified and given a 'human' body. Earlier, the camera apparatus is foregrounded in a way suggesting something underhand about it: having agreed to Agee and Evans's project, Harmon, the New Deal executive, and his associate, 'showed that they felt they had been taken advantage of, but said nothing of it' when 'they saw the amount of equipment stowed in the back of our car' (23).

The microscopic focus of Agee's text records his attempt, as it were, to turn himself into a verbal camera; his text, in its exploration of feelings, anecdote, background, narrative, contradictions, does a plethora of things that photography cannot. During his three-week stay with the Gudgers, Agee 'lived, slept, ate, and worked side by side with the family' (Bergreen, 171), observing everything: 'no detail was too homely to escape his inventory' (Bergreen, 173). Agee even catalogued everything in the Gudger and Ricketts' houses in the static, almost supernaturally descriptive section of his book entitled 'Shelter'. But he also wrote with an inflamed subjectivity, understanding that his knowledge of his subjects 'depends as fully on who I am' (211) as on who they are. He plunged into his subjects' lives with his writing, declaring his sexual desires, and concocting fantasies.

The duality of Evans's portraits, meanwhile, also suggests the extent to which photography is highly intersubjective, selective and reciprocal, especially in its portraits of people. Praising Evans's photograph of Annie Mae Gudger (her name in Agee's text), ${ }^{15}$ Lionel Trilling noted how 'it was "sat for" and "posed" (as quoted in Stott, 277) as a portrait, giving its subject greater dignity. ${ }^{16}$ There is a profound difference between this process and portraiture produced with the subject unaware. The subject has greater agency and control. Trilling also saw how Evans's portrait gave its subject freedom from 'objectivity':

The gaze of the woman returning our gaze checks our pity [...] In this picture, Mrs. Gudger, with all her misery and perhaps with her touch of pity for herself, simply refuses to be an object of your 'social consciousness'; she refuses to be an object at all-everything in the picture proclaims her to be all subject. And this is true of all of Evans' pictures of the Gudger, Woods and Ricketts families (as quoted in Stott, 278). 


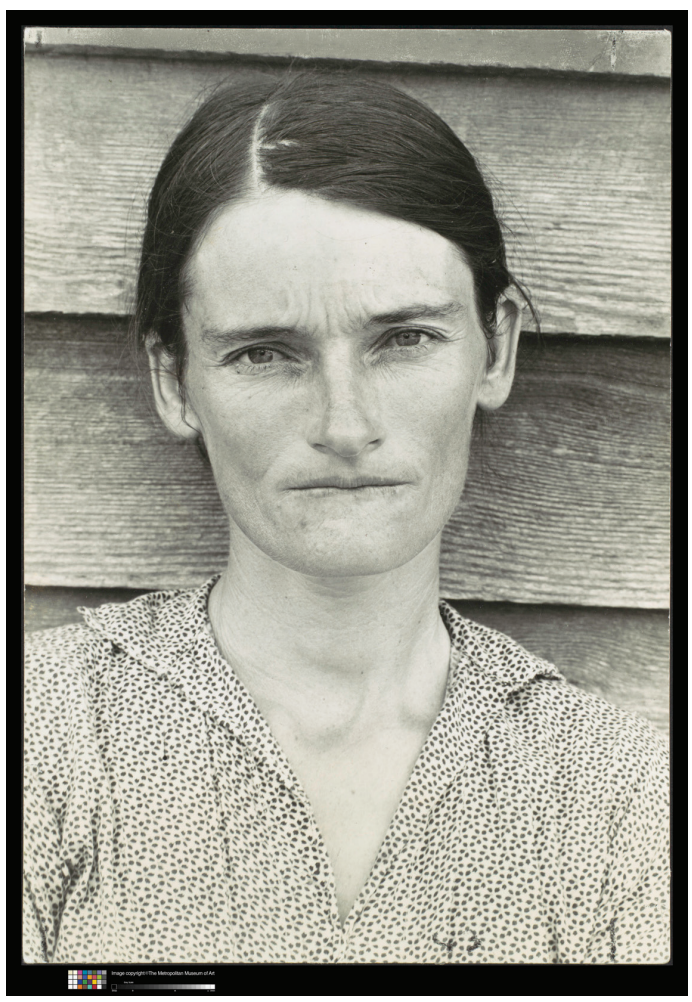

Walker Evans, Alabama Tenant Farmer Wife, 1936. (C) Walker Evans Archive, The Metropolitan Museum of Art.

The camera served as an ideal for many writers of reportage, particularly in the Thirties: of how they could convey other people's lives, if only it were possible to shed one's background, standpoint, and prejudices, and work with utter transparency. But Christopher Isherwood's famous line in Goodbye to Berlin (1939) - 'I am a camera with its shutter open, quite passive, recording, not thinking' (243) — is perhaps most interesting for the ways in which it highlights how human and mechanical methods of recording often bleed into each other. For many writers, camera-like transparency remains an illusion, an aspiration, a possibility rather than a reality. Martha Gellhorn, as Kate McLoughlin notes, used a similar metaphor for reportorial objectivity (a notion she distrusted). She 'likened it to being a "walking tape recorder with eyes", an image which encapsulates the idea of mechanical, emotionless, unmediated transcription' (59). 
But for Gellhorn, this 'becomes not so much a figure for genuineness as for a certain tonal control (albeit a control which on occasion "slips" or "blinks") appropriate to the solemn task of bearing witness' (59). For Agee, the camera's example encouraged transcendental accuracy; and its eye greatly increased his own reflective subjectivity in his prose.

\section{‘WHAT WE SAW AND HEARD': STEINBECK AND CAPA IN RUSSIA}

For John Steinbeck, travelling with Robert Capa to Russia in the late Forties to write A Russian Journal (1948), a camera-like transparency was also the avowed ideal, and again one feels how the objectivity of the camera is over-emphasised, even idealised. Steinbeck and Capa decided early on in their collaboration that they 'would try to do honest reporting, to set down what we saw and heard without editorial comment' (4). Where for Agee the camera's example inspired an avidity for the endless apprehension of the real, for Steinbeck the notion of a certain purity and lack of bias is paramount. Steinbeck writes:

Probably the hardest thing in the world for a man is the simple observation and acceptance of what is. Always we warp our pictures with what we hoped, expected, or were afraid of [...] it is very good to have photographs, because a camera has no preconceptions, it simply sets down what it sees (33).

Yet in A Russian Journal Steinbeck also narrates all the difficulties and triumphs Capa faced with his camera throughout their trip, making us, even more so than in Agee, very conscious of the artifice, or the performative nature, of photographic portraits, as well as of their arbitrariness. In one sequence where text and image are particularly well-matched, Steinbeck and Capa visit a farm village, and once out in the fields, as Steinbeck writes, 'Capa's cameras caused a sensation [...] There was one woman, with an engaging face and a great laugh, whom Capa picked out for a portrait. She was the village wit. She said, "I am not only a great worker, I am twice widowed, and many men are afraid of me now." And she shook a cucumber in the lens of Capa's camera. And Capa said, "Perhaps you'd like to marry me now?" (74-5). It is a scene which humorously opens up and exposes another crucial element of standpoint: gender and sexuality. The text of this encounter in A Russian Journal runs beneath an arrangement of four photographs of the peasant woman, talking and gesticulating. In their tone these photographs contrast sharply with the rebuffed pity and inner dignity of Walker Evans's photographs in Let Us Now Praise Famous Men, showing the vivacity and multiplicity of the woman they portray. The almost 
filmic arrangement of the four photographs allows no individual portrait to become the 'truth'.

The problems Steinbeck and Capa faced in Russia were not so much to do with the considerable linguistic and cultural barriers they facedalthough their inability to understand the language was nonetheless a major issue-or the ethical conundrums concerning the depiction of poverty that so affect the comparable work of Orwell, London and Agee. They were on much more unfamiliar territory, although Orwell, in Homage to Catalonia, comes closest to their experiences. Rather than the problems of invasiveness and privacy, for Steinbeck and Capa omission was the most troubling aspect-what was being left out of the picture. The main concern of A Russian Journal becomes how their experience was hindered by the Russians, who only allowed them to visit certain places, spied on them throughout, and engineered their itinerary so that there remains an extremely valid doubt in Steinbeck's account about how much they had seen in Russia. The problem of 'access' faced here is perhaps more familiar to war reporters, embedded or restricted in their view, than it is akin to the barriers experienced by Orwell, London, and Agee in their lives of the poor. Unfamiliarity, for Steinbeck and Capa, allowed for vivacity in their portraits, but it also meant they were duped in their account of Stalinist Russia.

Steinbeck's word portraits are self-consciously apolitical. 'We shall write what we saw and heard' (8), Steinbeck declares early on-meaning he would write only that. Where Agee's aim was to avoid shrinking his subjects to make them 'representative', the long-standing issue with A Russian Journal has been its failure to represent how its descriptions of individuals form an accurate account of the Soviet Union at that time. As Alex Kershaw notes, to take just one example, 'Steinbeck's text would make no mention of the 1946 famine that had killed millions of rural Russians or of the severe rationing that existed throughout the Soviet Union' (189). Nor was there any mention of Stalin's gulags. The tone of Steinbeck's writing is almost wilfully naïve at points, although Capa's photographs of peasants, ruins, and workers are often more matter-offact. However, as Susan Shillinglaw argues, 'the structure they chose for their book-indeed, the dominant metaphor of A Russian Journalis the Soviet Union as a framed portrait' (ix), in which what was shown of Stalin's domain was always going to be sharply 'circumscribed' (xii). One of the classic critiques of journalistic objectivity-that in some ways it can be easier to produce a 'balanced' account rather than making the effort to engage and take sides-applies strongly here. As Joan 
Didion wrote in 1996, writing of a very different context, "what "fairness" has often come to mean is a scrupulous passivity, an agreement to cover the story not as it is occurring but as it is presented, which is to say as it is manufactured' ('The Deferential Spirit').

Yet compared to Agee's tangles of maze-like lyricism, Steinbeck's equally lyrical prose does give glimpses of how it might be possible to simply 'write what we saw and heard', like a camera. It reveals how clarity, minimalism and slightly detached observation-as opposed to Agee's accretive maximalism and highly involved imaginative interiority-can work together to provide a sympathetic, passionate portrait of unfamiliar characters living ordinary lives. A Russian Journal flirts with a deliberate superficiality, yet it is more complex than it seems, above all in how it depicts Steinbeck and Capa's handling by the Russians, and how their trip was stage-managed. The text itself alludes to this constantly in Steinbeck's account of the obstructions they faced. And the very first photograph in A Russian Journal shows the view from the room in the Savoy Hotel in Moscow where they stayed. It is a photograph about being watched, and photographed, as Steinbeck explains:

Three huge double windows overlooked the street. As time went on, Capa posted himself in the windows more and more, photographing little incidents that happened under our windows. Across the street, on the second floor, there was a man who ran a kind of camera repair shop. He worked long hours on equipment. And we discovered late in the game that while we were photographing him, he was photographing us (21).

Another image of photographers photographing each other appears, more optimistically, later on in A Russian Journal, with a picture by Capa of a photographer in Stalingrad, taking a portrait of 'a stern young army recruit' (126), as Steinbeck recounts. 'The photographer looked around and saw Capa photographing him and the soldier. He gave Capa a fine professional smile and waved his hat' (126). While Capa takes the photograph of the boy sitting for his photograph, Steinbeck's clipped record also suggests how all four figures seemed to understand each other, interacting from different points of view, all engaged in different ways in the process of recording a portrait. And playfully alluding to the inter-relation of the mechanical and human elements in photographic portraiture, the photographer's hat which Steinbeck mentions in his text can be seen in Capa's photograph on the top of the camera tripod. 


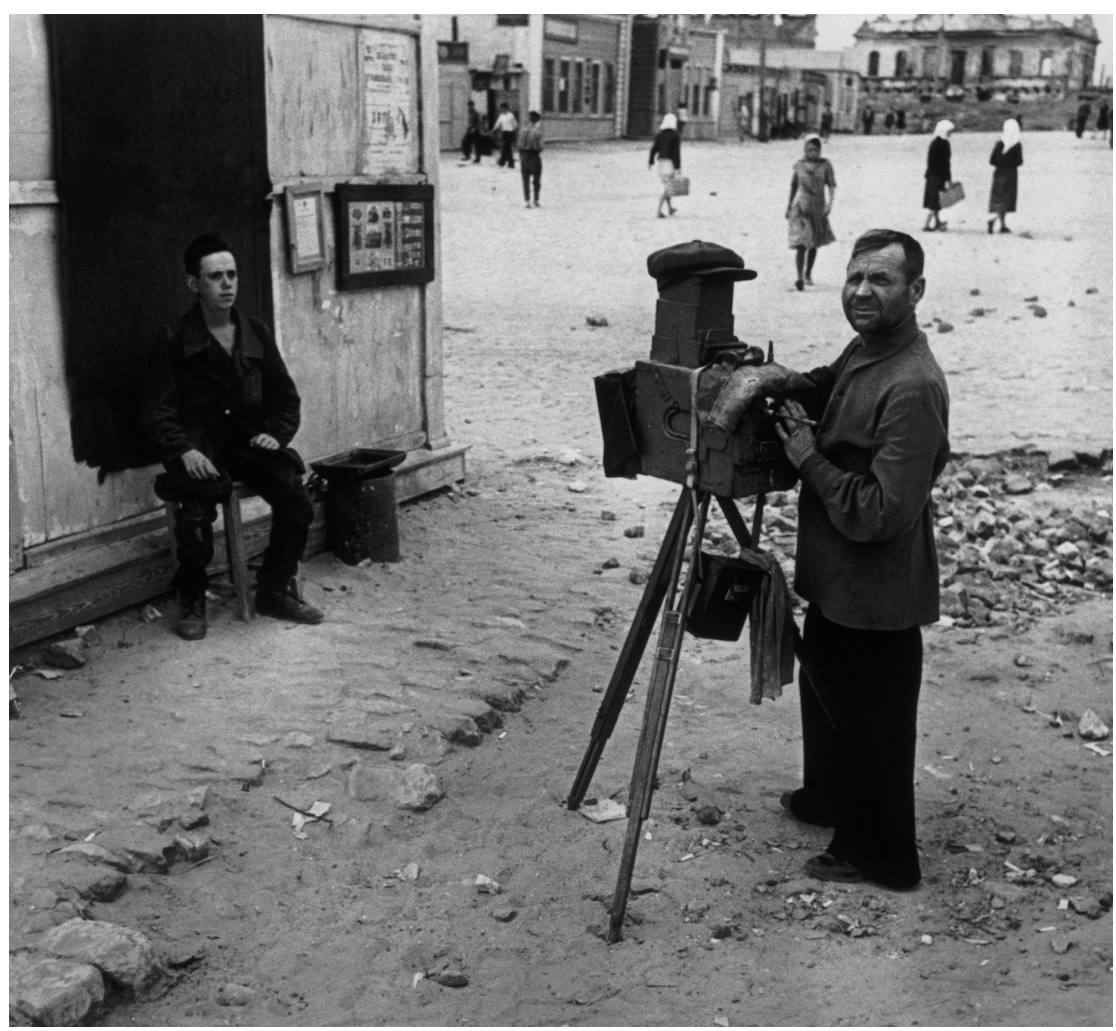

(C) Robert Capa / International Center of Photography / Magnum Photos.

The camera is almost the central figure in this image: the pivot of the interplay between the odd quartet of people. The photograph operates succinctly as an acknowledgement of the subtlety, difficulty, and unfamiliarity of standpoint in reportage work-faced differently by Orwell, London, Agee and Steinbeck-and faced by writers and photographers, and writers working with photographers. 'What I saw'- that refrain one often finds in reportage-is often shaped as much by the ' $I$ ' as by the 'what'; and the 'what', indeed, defined by where one happens to be standing at a certain point in time.

In summary, visual and literary portraiture in reportage and documentary writing is interactive, intersubjective, and heavily informed by the standpoint of the writer or photographer. It is particularly freighted with difficulty in the way that it involves portraying, and speaking for, other, often unfamiliar people, and in the ways that it makes them representative. 
With the advent of the camera, and the profession of war reporting in particular developing in the Thirties, ${ }^{17}$ many writer-reporters idealised and incorporated photography in their work, perhaps specifically to attempt to erase or elide these difficulties of standpoint. But in practice the combination of verbal and visual photographic portraiture, rather than eliminating these problems, often served to add a further layer of complexity-even more so in the context of the Communist espionage of the period, which Orwell, Agee, and Steinbeck all used as a motif in their documentary and reportage books. Standpoint in the portraiture in reportage, as we have seen, is continually shifting, under question, and in flux, and the interplay between the roles of observer and observed, reporter and subject, should never be taken for granted.

\section{WORKS CITED}

Agee, James. 'Notes on Book of Subway Photographs.' In: Michael A. Lofaro and Hugh Davis (eds.), James Agee Rediscovered. Knoxville: University of Tennessee Press, 2005, 301-305.

Agee, James and Walker Evans. Let Us Now Praise Famous Men. London: Penguin, 2006.

Allred, Jeff. American Modernism and Depression Documentary. New York: Oxford, 2010.

Ashplant, T. G. 'Life Writing "from Below" in Europe: Introduction.' European Journal of Life Writing 7 (2018) 1-9, https://ejlw.eu/article/view/31502, doi: 10.5463/ejlw.7.237. Date accessed: 18 April 2020.

Ashplant, T. G. 'Life Writing "from Below" in Europe: Authors, Archives, Avenues, Arenas.' European Journal of Life Writing 7 (2018) 10-48, https://ejlw.eu/article/view/31503, doi: 10.5463/ejlw.7.241. Date accessed: 18 April 2020.

Bak, John S. 'Introduction.' In: John S. Bak and Bill Reynolds (eds.), Literary Journalism Across the Globe: Journalistic Traditions and Transnational Influences. Amherst: University of Massachusetts Press, 2011, 1-20.

Benjamin, Walter. 'The Author as Producer.' In: Anna Bostock (Trans.), Understanding Brecht. London: Verso, 1998, 85-103.

Bergreen, Laurence. James Agee: A Life. New York: Dutton, 1984.

Bourriaud, Nicolas. Relational Aesthetics. Dijon: Les Presses Du Réel, 1998.

Bowker, Gordon. George Orwell. London: Abacus, 2004.

Brilliant, Richard. Portraiture. London: Reaktion, 1991.

Cartier-Bresson, Henri. The Mind's Eye: Writings on Photography and Photographers. New York: Aperture, n.d.

Clayton, Owen. 'Literature of Attractions: Jack London and Early Moving Images.' In: Robin Peel and Daniel Maudlin (eds.), Transatlantic Traffic and (Mis)Translations. New Hampshire: UP of New Hampshire, 2013, 197-220.

Coles, Robert. Doing Documentary Work. New York: Oxford, 1997.

Crick, Bernard. George Orwell: A Life. London: Penguin, 1992.

Davis, Hugh. The Making of James Agee. Knoxville: University of Tennessee Press, 2008.

Didion, Joan. 'The Deferential Spirit.' The New York Review of Books 43:14 (19 September 1996) 14-19, https://www.nybooks.com/articles/1996/09/19/the-deferential-spirit/. Date accessed: 18 April 2020.

Gellhorn, Martha. The View from the Ground. London: Granta, 1990.

Gidley, Mick. 'Hoppé's Impure Portraits: Contextualising the American Types.' In: Graham Clarke (ed.), The Portrait in Photography. London: Reaktion Books, 1992, 132-154. 
Hartsock, John C. 'Literary Reportage: The "Other” Literary Journalism.' Genre 152 (Spring/ Summer 2009) 113-134.

Hedrick, Joan D. Solitary Comrade: Jack London and his Work. Chapel Hill: University of North Carolina Press, 1982.

Isherwood, Christopher. The Berlin Novels. London: Vintage, 1999.

Jackson, Bruce. Pictures from a Drawer: Prison and the Art of Portraiture. Philadelphia: Temple University Press, 2009.

Kapuściński, Ryszard. 'Herodotus and the Art of Noticing.' New Perspectives Quarterly 21 (2004) 50-53.

Kerrane, Kevin. 'Making Facts Dance.' In: Kevin Kerrane and Ben Yagoda (eds.), The Art of Fact: a Historical Anthology of Literary Journalism. New York: Touchstone, 1997, 17-20.

Kershaw, Alex. Blood and Champagne: the Life and Times of Robert Capa. London: Macmillan, 2002.

Labor, Earle. Jack London: an American Life. New York: Farrar, Straus and Giroux, 2014.

Lemann, Nicholas. 'The Art of Fact.' The New Yorker, 29 April 2019, 66-70, https://www. newyorker.com/magazine/2019/04/29/john-hersey-and-the-art-of-fact. Date accessed: 18 April 2020.

London, Jack. The People of the Abyss. London: Tangerine Press, 2014.

Maras, Steven. Objectivity in Journalism. Cambridge: Polity Press, 2013.

Marcus, Laura. 'The Creative Treatment of Actuality: John Grierson, Documentary Cinema and "Fact" in the 1930s.' In: Kristin Bluemel (ed.), Intermodernism: Literary Culture in MidTwentieth Century Britain. Edinburgh: Edinburgh UP, 2009.

McLoughlin, Kate. Martha Gellhorn: the War Writer in the Field and in the Text. Manchester: Manchester, 2007.

Mellow, James R. Walker Evans. New York: Basic Books, 1999.

Nochlin, Linda. 'Some Women Realists.' Arts Magazine, May 1974, 29-33.

North, Joseph. 'Reportage.' In: Henry Hart (ed.), American Writers' Congress. New York: International, 1935, 120-23.

Ophir, Ella Zohar. 'Romantic Reverence and Modernist Representation: Vision, Power, and the Shattered Form of Let Us Now Praise Famous Men.' Twentieth Century Literature 53:2 (2007) 125-152.

Orwell, George. 'A Kind of Compulsion: 1903-1936.' In: Peter Davison, Ian Angus, and Sheila Davison (eds.), Volume 10 of The Complete Works of George Orwell. London: Secker \& Warburg, 1998.

Orwell, George. Homage to Catalonia. London: Penguin, 2000.

Orwell, George. Down and Out in Paris and London. London: Penguin, 2001.

Orwell, George. The Road to Wigan Pier. London: Penguin, 2001.

Reesman, Jeanne Campbell, Sara S. Hodson, and Philip Adam. Jack London, Photographer. Athens, GA: University of Georgia Press, 2010.

Seaber, Luke. Incognito Social Investigation in British Literature: Certainties in Degradation. Basingstoke: Palgrave Macmillan, 2017.

Schaffer, Kay and Sidonie Smith. 'Conjunctions: Life Narrative in the Field of Human Rights.' Biography 27:1 (2004) 1-24.

Schjeldahl, Peter. 'Exposed: The Photography of Garry Winogrand and Jeff Wall.' The New Yorker, 13 May 2019, 60-62, https://www.newyorker.com/magazine/2019/05/13/garrywinogrand-and-jeff-wall-photography-in-two-phases. Date accessed: 18 April 2020.

Schudson, Michael. Discovering the News: A Social History of American Newspapers. New York: Basic Books, 1978.

Shillinglaw, Susan. 'Introduction.' In: John Steinbeck and Robert Capa (eds.), A Russian Journal. London: Penguin, 2000.

Sinclair, Iain. 'The Screaming Streets: Jack London's Maelstrom.' Introduction to The People of the Abyss. London: Tangerine Press, 2014, 13-15. 
Sontag, Susan. Regarding the Pain of Others. London: Penguin, 2004.

Steinbeck, John and Robert Capa. A Russian Journal. London: Penguin, 2000.

Stott, William. Documentary Expression and 1930s America. New York: Oxford, 1973.

Ward, Stephen J.A. The Invention of Journalism Ethics: the Path to Objectivity and Beyond. Montreal: McGill-Queen's University Press, 2008.

Williams, Keith. 'Post/Modern Documentary: Orwell, Agee and the New Reportage.' In: Keith Williams and Steven Matthews (eds.), Rewriting the Thirties: Modernism and After. London: Longman, 1997, 163-181.

Wolfe, Tom. 'The New Journalism.' In: Tom Wolfe and E.W. Johnson (eds.), The New Journalism. London: Picador, 1975, 15-68.

Woodall, Joanna. 'Introduction: Facing the Subject.' In: Joanna Woodall (ed.), Portraiture: Facing the Subject. Manchester: Manchester University Press, 1997, 1-25.

\section{ABOUT THE AUTHOR}

Jerome Boyd Maunsell is the author of the biography Susan Sontag (Reaktion, 2014) and the group biography Portraits from Life: Modernist Novelists and Autobiography (Oxford, 2018). His essays and reviews have appeared in frieze and the TLS. He is a Lecturer in the Department of English and Creative Writing at the University of Roehampton, London. Email:Jerome.Maunsell@roehampton.ac.uk.

\section{NOTES}

This work was supported by the Leverhulme Trust, as part of a Leverhulme Early Career Fellowship.

1 For many critics and commentators, the inclusion of fictional elements, obviously, disqualifies a piece of writing from being non-fiction, however 'creative'. 'The relationship between fiction and nonfiction is like the one between art and architecture: fiction is pure, nonfiction is applied,' writes Nicholas Lemann in a useful analogy. 'Just as buildings shouldn't leak or fall down, nonfiction ought to work within the limits of its claim to be about the world as it really is' ('The Art of Fact', 70).

2 As Kate McLoughlin writes, documentary derives 'from the Latin, documentum-proof, lesson (docere, to teach) (OED). The French term for travel films was "documentaires" (51).

3 The New Journalism of the Sixties was, as has often been pointed out, nothing new even as a term. Indeed, as Kevin Kerrane writes, 'the term "new journalism", in fact, was originally coined by Matthew Arnold in 1887 to describe the style of [W.T.] Stead's Pall Mall Gazette' (17).

4 For John C. Hartsock, who tends to favour the term 'literary journalism', 'literary reportage' is a distinctly European tradition, and 'a much more "elastic" form than that of American literary journalism' ('Literary Reportage', 114). Throughout this article, however, I have generally favored the terms 'documentary' and 'reportage' over 'literary journalism'. I have done this partly because during the early twentieth century, the terms 'documentary' and 'reportage' were much in use; partly as the writers I am dealing with-Agee, London, Orwell, Steinbeck—were all novelists, who published the results of their investigations in book form (although they all undertook journalistic assignments too); and partly as the derivation of reportage, from the Latin reportare, 'to carry back', 
embodies much that is central to this elusive mode of writing. In Britain, 'literary journalism' has also long been used for journalism dealing specifically with literature-for example, book reviewing. 'Reportage' has important precedents in Britain in its use for several decades by the publisher Granta, and in Ian Jack's The Granta Book of Reportage (1993) and John Carey's The Faber Book of Reportage (1987).

5 Kapuściński's work, for example, has increasingly been assessed by critics in terms of how much it blurs the boundaries between fact and fiction. For many commentators, Kapuściński's procedures are deeply problematic, as for example, in Artur Domosławski's biography Kapuściński Non-Fiction (London: Verso, 2010). For Domosławski, Kapuściński's reportage is better viewed, simply, as fiction. Arguments about veracity and fictionality have also dominated discussions of earlier documentary texts, reportage and literary journalism by other writers.

6 Gender plays a crucial role in reportage, especially in terms of access, but this is not the focus of this article and would merit further study. Kate McLoughlin offers a useful survey of central issues facing female war reporters, in particular, in her chapter 'Being there: the field' in Martha Gellhorn: the War Writer in the Field and in the Text, in which she notes that 'the granting and gaining of access to conflict tends to disadvantage women war recorders, a phenomenon Martha Gellhorn experienced personally'.

7 Richard Brilliant writes that 'simply put, portraits are art works, intentionally made of living or once living people by artists, in a variety of media, and for an audience'. (Portraiture, 8).

8 As T.G. Ashplant notes, "the term life writing "from below" [...] draws on an analogy with the now well-established formulation "history from below", and concerns texts and forms of life writing 'by authors outside (predominantly male) elites' (1), from social groups who for reasons of 'class or status hierarchy' (1), or 'gender, race, ethnicity, nationality, religion, sexuality-have had little or no access to the necessary resources $[\ldots]$ for recording their story, for making their voices heard' (2).

9 Hugh Davis, in The Making of James Agee, also explores the influence of Surrealism on Agee in his chapters ' It Is Funny If I Am a Surrealist": Agee and the Avant-Garde', and "'Syncopations of Chance": Let Us Now Praise Famous Men as Surrealist Ethnography'.

10 Woodall also points out how the advent of photography in the nineteenth century shifted the terms of the 'portrait transaction', as photographs 'admitted an unprecedentedly wide clientele to portraiture, enabling people who could not previously afford, or were not considered worthy of, painted immortality to have their features recorded for posterity' (6).

11 Orwell himself tentatively acknowledged this in Wigan Pier when he wrote of Down and Out that 'nearly all the incidents described there actually happened, though they have been rearranged' (142). In 1935, Orwell had slightly contradicted this (his 'nearly all' is 'everything'): 'I did not feel I had to describe events in the exact order in which they happened, but everything I have described did take place at one time or another' (A Kind of Compulsion, 353).

12 As Luke Seaber writes, Orwell in Down and Out did not present himself as a social investigator, suggesting that 'he is there not through choice to observe but through necessity [...] this stance of Orwell's is disingenuous pretence, but still a very subtle way of asserting his authority as one who has truly known poverty' (69).

13 For more on Jack London's photography, see Jeanne Campbell Reesman, Sara S. Hodson and Philip Adam, Jack London, Photographer.

14 Walker Evans attempted an interesting experiment in this regard in his photographs of riders on the New York subway of 1938-1941, in which he surreptitiously took the photographs with a hidden camera. As James Agee wrote about these subway photographs, in 
some rough drafts dating from 1940, 'insofar as was possible, those who were being photographed were kept unaware of the fact' ('Notes', 302). This, in Agee's view, enhanced the power of the photographs: 'To ride watchfully, in a New York Subway, is a dreadful and piteous act of surreptition: for in its noise and motion, in its suspension, almost every human being is unmasked, and unaware of being unmasked, and unaware of being watched' ('Notes', 303). These were perfect 'laboratory conditions' ('Notes', 305), Agee thought, for the study of the soul.

15 'Annie Mae Gudger' has also been referred to as 'Ellie Mae Burroughs' and 'Allie Mae Burroughs'-and Evans's iconic photograph of her in Let Us Now Praise Famous Men is also titled 'Alabama Tenant Farmer Wife'.

16 William Stott also pointed out, in 1973, that 'no one has noticed that there are two Annie Mae Gudgers: she of Let Us Now Praise Famous Men and she of Evans' American Photographs (1938). The differences between the two women are real and complex, but it is no doubt significant that the Annie Mae of the documentary book is more acute, puzzled, and bitter' (277).

17 As Susan Sontag notes in Regarding the Pain of Others, 'it was precisely in the late 1930s that the profession of bearing individual witness to war and war's atrocities with a camera was forged' (28). 